Research Article

\title{
Hospital Management Information Systems Acceptance at Wonosari Regional Hospital, Gunungkidul, Yogyakarta, Indonesia
}

\author{
Ahmad Samratul Aula ${ }^{1, *}$ \\ ${ }^{1}$ Department of Public Health, Ahmad Dahlan University, Yogyakarta, Indonesia \\ *Correspondence: aulachmad8@gmail.com. Phone: +6282141450570
}

Received 31 January 2021; Accepted 03 March 2021; Published 04 March 2021

\begin{abstract}
Background: The hospital management information system (HMIS) is a computer system that processes entire health care business processes, including reporting and administrative procedures, to obtain information quickly, precisely, and accurately. The Wonosari Regional Hospital is a type B hospital that has implemented the HMIS. This study aimed to analyse the HMIS use in the Wonosari Regional Hospital, Gunungkidul, Yogyakarta.

Method: This is a quantitative study using a cross sectional design. Seventy-nine staffs participated in this study that recruited using the purposive sampling technique. Data were collected using a pre-tested questionnaire, then analysed statistically.

Results: Perceived ease of use was found significant associated with HMIS use ( $p$-value $\leq$ 0.05).

Conclusion: Perceived ease of use influenced the use of HMIS at the Wonosari Regional Hospital, Gunungkidul, Yogyakarta
\end{abstract}

Keywords: Sex; Ease of use; Usefulness; Attitude; SIMRS

\section{INTRODUCTION}

Information systems are a method to collect, enter, proceed, and store data and manage, control, and report information in such a way to support the organisation goals (1). The information system is a strategy to provide customer-oriented services or health service users, including in hospital settings. Hospital customers can be internal and external customers. Internal customers are all parties in the hospital environment, including the owner, management, and hospital employees. Meanwhile, external customers are more hospital services users, including patients, patient families, partners, suppliers, and the wider community (2).

An information system is related to computers usage. The availability of computers used is an essential element for the hospital to run HMIS. The hospital unit that runs HMIS includes 
patient management, clinical management, medical diagnosis, supply management, financial management, support services, and the education and research section (3). Based on the Regulation of Indonesia Minister of Health (Menkes RI) Number 82 of 2013, article 3 about Hospital Management Information Systems explains that all hospitals in Indonesia are required to use HMIS to facilitate the exchange and produce appropriate, accurate, and renewable information - within and between the hospital, as well as to the ministry of health. Refer to that regulation, the HMIS application can be sourced from the ministry of health or can be developed by the hospital but must comply with the ministry of health (4).

In the hospital setting, generally, they develop HMIS by involving the external IT vendor. This cooperation tied in the long term, including upgrading and maintaining software in the HMIS (5). Apart from that, the functionality of the system is also an essential factor in implementing HMIS. The availability of a system will be adequate if it builds based on the hospital staff's necessity. HMIS ease of use is one of the consideration during system development (6).

The Technology Acceptance Model (TAM) is a theory about the use of information systems that are considered very influential and is generally used to explain the individual acceptance of information technology systems. The TAM's basic concept is perceived usefulness and ease of use, which means a person's perception of using information systems useful in an organisation. The TAM has many advantages, including the behaviour model that is useful for answering why many information systems are not sustained because users do not intend to use technology (7).

Based on the preliminary study conducted at the Wonosari Regional Hospital, Gunungkidul, Yogyakarta, it is known that this hospital using HMIS for some years. The was shifting of the HMIS in term of the improvement process from the vendor to the hospital's internal IT. HMIS in this hospital is integrated with all unit in the hospital. All this time, some employees feel complaining about operation HMIS during the transition. Accordingly, an acceptance analysis is needed to see the challenge of system implementation.

\section{METHOD}

A quantitative study with a cross sectional design was conducted in the Wonosari Regional Hospital of Gunungkidul, Yogyakarta, from March-May 2020. The population for this study was all staffs experienced in operating the HMIS $(n=260)$. The sample was calculated using the Raosoft sample size calculator with a 95\% confidence level and a 10\% margin of error. Based on the calculation, the minimum sample size was 71 , and we added $10 \%$ as an alternative sample. Thus, in total, we selected and collected 79 samples chosen using incidental sampling. 
A set of pre-tested questionnaire was used to collect the data from the respective respondent.

Chi-square test was employed to see the association among the variable involved refer to TAM concept.

\section{RESULTS}

\section{Characteristic of Respondent}

Table 1 shows the characteristic among 79 respondents. Most of the respondent was male (70.9\%). More than half of the respondents stated comfortable using current HMIS, but more than $60 \%$ said the HMIS not beneficial for them. Almost $70 \%$ of the respondent reported an excellent attitude toward using HMIS.

Table 1. Respondent Characteristic

\begin{tabular}{ll}
\hline \multicolumn{1}{c}{ Characteristic } & N (\%) \\
\hline Sex & \\
Male & $56(70.9)$ \\
Female & $23(29.1)$ \\
\hline Perception ease of use & \\
Challenging & $38(48.1)$ \\
Comfortable & $41(51.9)$ \\
\hline Perception of usefulness & \\
$\quad$ Not useful & $51(65.8)$ \\
Useful & $27(34.2)$ \\
\hline Attitude & $24(30.4)$ \\
Poor & $55(69.6)$ \\
Good &
\end{tabular}

\section{Statistical analysis}

Chi-square test in Table 2 shows there was no relationship between HMIS used in Wonosari Regional Hospital versus Sex, perception of usefulness and attitude. The only perception of ease of use was significantly associated with HMIS ( $p$-value $=0.03$ ).

Table 2. Relationship Between Sex and HMIS Use

\begin{tabular}{|c|c|c|c|c|c|c|c|}
\hline \multirow{3}{*}{ Variable } & \multicolumn{6}{|c|}{ HMIS Use } & \multirow{3}{*}{ P-value } \\
\hline & \multicolumn{2}{|c|}{ Poor } & \multicolumn{2}{|c|}{ Good } & \multicolumn{2}{|c|}{ Total } & \\
\hline & $\mathrm{N}$ & $\%$ & $\mathrm{~N}$ & $\%$ & $\mathrm{~N}$ & $\%$ & \\
\hline \multicolumn{7}{|l|}{ Sex } & \multirow{3}{*}{0.70} \\
\hline Female & 29 & 36.7 & 27 & 34.2 & 56 & 70.9 & \\
\hline Male & 13 & 16.5 & 10 & 12.6 & 23 & 29.1 & \\
\hline \multicolumn{8}{|c|}{ Perception ease of use } \\
\hline Challenging & 25 & 31.6 & 13 & 16.5 & 38 & 48.1 & \multirow[t]{2}{*}{0.03} \\
\hline Comfortable & 17 & 21.5 & 24 & 30.4 & 41 & 51.9 & \\
\hline \multicolumn{8}{|c|}{ Perception of usefulness } \\
\hline Not useful & 27 & 34.2 & 25 & 31.6 & 52 & 65.8 & \multirow[t]{2}{*}{0.75} \\
\hline Useful & 15 & 19.0 & 12 & 15.2 & 27 & 34.2 & \\
\hline \multicolumn{8}{|l|}{ Attitude } \\
\hline Poor & 26 & 32.9 & 28 & 35.4 & 54 & 30.4 & \multirow[t]{2}{*}{0.18} \\
\hline Good & 16 & 20.3 & 9 & 11.4 & 25 & 69.6 & \\
\hline
\end{tabular}




\section{DISCUSSION}

This study aims to assess the relationship between the usage of HMIS and some variables related to the perception of using the HMIS as part of the TAM model conducted in Wonosari Regional Hospital, Gunungkidul. Among the four-variable assessed sex, perceived ease of use, perception of usefulness and attitude on HMIS, we found the only perception of ease of use has a significant association with the HMIS use, and the three other variables are not associated.

Perceived ease of use is the primary variable that influencing the acceptance of HMIS in the research location. This finding highlighted that during the HMIS development, literary procedure to test the system is essential to know the needs and the ease of using the system. Our discovery was strengthening by some previous researches that perceived ease of use was determinant for the benefit of HMIS in particular hospital (8-10).

In our research being male of females do not influence the respondent acceptance of HMIS. This study's results follow previous research that showed that gender did not significantly affect perceived usefulness - in another word that sex is not an obstacle in the application of technology even though in some settings it could be a problem due to the social norm (11)(12). In our research setting, perception of usefulness is not influenced by respondent sex of the employee because, in the application, all employees are given the same direction on using the HMIS.

Users believe that using an information system improves their performance on completing their job (13). This illustrates the system's usefulness from the user point of views that promising for the hospital management to continue using the HMIS. Our result is in line with the previous research that showed the higher desire of medical staff to adopt technology because they acknowledge the system's usefulness (14)(15). Perceived use among users explained that HMIS rolled on accelerating their work, simplifying their medical record data storage, improving performance in managing hospital data, and facilitating patient data management. Our result found that respondent reported negatively perceived usefulness related to the HMIS in their workplace. Our observation supported that the HMIS could not facilitate the finding process of the medical record. This research matches previous research that states that user perceptions of the usefulness of information technology affect the acceptance of information technology systems (16). Still, it differs from previous research that perceives usefulness as the predictor of technology acceptance (17). This is related to the absence of interest for employees in the organisation's goals as a whole so that the system's usefulness does not increase their desire to use the system. 
A good attitude towards HMIS is related to the feeling that HMIS provides a good impact on the hospital, user volunteer using the system, feeling safe storing the data and simplifying their work. In this study, we found that attitude did not influence HMIS use. Our finding is in line with former research, which states that user attitudes towards use do not significantly affect the acceptance of Information Technology. This is also consistent with Sun's study, which found that attitude was not a predictor of behavioural interest or the use of HMIS (18) but in contrast with research in Malaysia that found attitude a significant predictor of using the technology (19).

\section{CONCLUSION}

Among the four-variable assessed sex, perceived ease of use, perception of usefulness and attitude on HMIS usage, we found the only perception of ease of use has a significant association with the HMIS use, and the three other variables are not associated.

\section{Authors' Contribution}

ASA contributed to designing the study, collected and analysed the data, and wrote the manuscript's first draft. SS contributed to developing the research and review the analysis and the manuscript draft.

\section{Funding}

This research did not receive external funding.

\section{Conflict of interest}

The authors declare there is no conflict of interest.

\section{REFERENCES}

1. Triandini E, Jayanatha S, Indrawan A, Werla Putra G, Iswara B. Metode Systematic Literature Review untuk Identifikasi Platform dan Metode Pengembangan Sistem Informasi di Indonesia. Indones J Inf Syst. 2019;1(2):63.

2. Hatta G. Pedoman Manajemen Informasi Kesehatan disarana Pelayanan Kesehatan. Pedoman Manajemen Informasi Kesehatan disarana Pelayanan Kesehatan. 2008.

3. Vaganova E, Ishchuk T, Zemtsov A, Zhdanov D. Health information systems: Background and trends of development worldwide and in Russia. Heal 2017 - 10th Int Conf Heal Informatics, Proceedings; Part 10th Int Jt Conf Biomed Eng Syst Technol BIOSTEC 2017. 2017;5(January 2017):424-8.

4. Menteri Kesehatan Republik Indonesia. Peraturan Menteri Kesehatan Republik Indonesia Nomor 82 Tahun 2013 tentang Sistem Informasi Manajemen Rumah Sakit. Peratur Menteri Kesehat Republik Indones Nomor 82 Tahun 2013 tentang Sist Inf Manaj Rumah Sakit. 2013.

5. Fattig M. Implementing a hospital information system: Lessons learned. Lab Med. 2007;38(5):317-8.

6. Ismail A, Jamil AT, A Rahman AF, Abu Bakar JM, Mohd Saad N, Saadi H. The implementation of Hospital Information System (HIS) in tertiary hospitals in Malaysia. 
Malaysian J Public Heal Med 2010. 2010;10(2):16-24.

7. Jogiyanto. Metodologi Penelitian Sistem Informasi. Yogyakarta: Andi; 2008.

8. He Y, Chen Q, Kitkuakul S. Regulatory focus and technology acceptance: Perceived ease of use and usefulness as efficacy. Cogent Bus Manag. 2018;5(1).

9. Putra DSH, Kurniawati R. Evaluasi Sistem Informasi Manajemen Rumah Sakit Dengan Metode Technology Acceptance Model ( TAM ) di Rumah Sakit X. J Rekam Med Dan Inf Kesehat. 2019;1(1):31-6.

10. Nurhayati, Arif YWT, Hidayah IN. Analisis Tingkat Penerimaan Pengguna Terhadap Teknologi Sistem Informasi Rekam Medis Di PKU Muhammadiyah Karanganyar. In: Prosiding Call For Paper SMIKNAS. 2019. p. 258-68. Available from: https://ojs.udb.ac.id/index.php/smiknas/article/view/694

11. Maruo M, Young D. Leveraging technology to close gaps between men and women. World Bank Blogs. 2018 [cited 2021 Mar 3]. Available from: https://blogs.worldbank.org/digital-development/leveraging-technology-close-gapsbetween-men-and-women

12. Sánchez-Franco MJ. Exploring the influence of gender on the web usage via partial least squares. Behav Inf Technol. 2006;25(1):19-36.

13. Söllner M, Hoffmann A, Leimeister JM. Why different trust relationships matter for information systems users. Eur J Inf Syst. 2016;25(3):274-87.

14. Gajanayake R, Sahama T, lannella R. The role of perceived usefulness and attitude on electronic health record acceptance. E-Health Telemed Concepts, Methodol Tools, Appl. 2015;1:49-59.

15. Alotaibi YK, Federico F. The impact of health information technology on patient safety. Saudi Med J. 2017;38(12):1173-80.

16. Santoso B. Pengaruh Perceived Usefulness, Perceived Ease of Use, dan Perceived Enjoyment Terhadap Penerimaan Teknologi Informasi. J Stud Akunt Indones. 2001;(1998):1-15.

17. Dyna H, Adi WP. Technology Acceptance Model of Mobile Ticketing. In: Proceedings of The 1st International Conference on Information Systems For Business Competitiveness (ICISBC) 2. 2011. p. 117-22. Available from: http://eprints.undip.ac.id/36105/

18. Sun H, Zhang P. A New Perspective to Analyze User Technology Acceptance. working Paper Syracuse University. 2003.

19. Hussein Z. Leading to Intention: The Role of Attitude in Relation to Technology Acceptance Model in E-Learning. Procedia Comput Sci. 2017;105(December 2016):15964. Available from: http://dx.doi.org/10.1016/j.procs.2017.01.196 